\title{
From thermal boredom to thermal pleasure: a brief literature review
}

Da monotonia térmica ao deleite térmico: uma breve revisão de literatura

\section{Christhina Candido Richard de Dear}

Christhina Candido Architectural and Design Science, Faculty of Architecture, Design and
Planning

University of Sydney Wilkinson Building (G04) 148 City Road

Tel.: (+612) 9351-3206 E-mail: christhina.candido@sydney.edu.au

Richard de Dear Architectural and Design Science, Faculty of Architecture, Design and

University of Sydney Tel.: (+612) 9351-2801

E-mail: richard.dedear@sydney.edu.au

Recebido em 24/10/11 Aceito em 15/02/12
Abstract

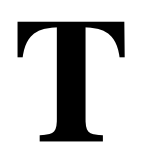
he most recent review of the ASHRAE Standard 55 (2010) incorporates the dialectic between static and adaptive approaches to thermal comfort by proposing different recommendations for airconditioned and naturally ventilated buildings. Particularly in naturally ventilated buildings, this standard aligns with three important topics in research field of thermal comfort during the last decades: (i) air movement enhancement versus draft, (ii) control availability and its impact on occupants' satisfaction, and (iii) the search for thermal pleasure. This paper presents the rationale behind these three research topics and discusses its positive influence when moving from thermal comfort towards thermal pleasure.

Keywords: Thermal comfort. Naturally ventilated buildings. Air movement. Control availability. Thermal pleasure.

\section{Resumo}

A mais recente revisão da ASHRAE 55 (2010) incorpora a dialética entre as abordagens estática e adaptativa de conforto térmico, propondo recomendações diferentes para edificações com ar-condicionado e naturalmente ventilados. Especialmente em ambientes naturalmente ventilados, esta versão da norma reflete três tópicos importantes de pesquisa na área de conforto térmico, presentes nas últimas décadas: (i) incremento do movimento do ar versus desconforto por correntes, (ii) a necessidade de mecanismos de controle ambiental e seu impacto na satisfação dos ocupantes e (iii) a busca de deleite térmico no ambiente construído. Este artigo apresenta a lógica por trás desses três tópicos de pesquisa e discute a influência positiva das mesmas, ao se ampliar a interpretação de conforto para deleite térmico.

Palavras-chave: Conforto térmico. Edifícios naturalmente ventilados. Movimento do ar. Controle ambiental. Deleite térmico. 


\section{Introduction}

The last decades have witnessed major international research efforts directed towards quantifying the relationship between the quality of the indoor environment, as perceived by occupants on the one hand and the physical character and intensity of the indoor environmental elements on the other (ROAF; CRICHTON; NICOL, 2009). The benefits of people spending more time inside artificial and controlled environments during their daily activities in order to keep them 'neutral' have been questioned (BRAGER; BAKER, 2009; ARENS et al, 2009; ZHANG et al., 2007a). But if we agree that those thermal environments which are slightly warmer than preferred or neutral can still be acceptable to building occupants, as the adaptive comfort model suggests (DE DEAR; BRAGER, 1998; AULICIENS, 1981; NICOL, 2004; HUMPHREYS, 1978), then the introduction of elevated air motion into such environments should be regarded as desirable because the effect will be to remove sensible latent heat from the body, thereby restoring body temperatures to their comfort set-points. The most recent review of the ASHRAE Standard (AMERICAN..., 2010) incorporates this rationale, adopting higher air speeds within the occupied zone and provision of occupants control over their indoor environments. These modifications are strongly aligned three important shifts on the thermal comfort research field associated to naturally ventilated buildings:

(a) air movement enhancement;

(b) control availability; and

(c) thermal pleasure.

The first shift refers to the recent revival of natural ventilation, as a passive design strategy, has been widening the range of opportunities available in buildings to provide comfort for occupants. One of the challenges when optimizing natural ventilation is to define when air movement is desirable and when not. Based on the argument that elevated air speeds in indoor environments could be unwelcomed (draft), air velocity limits have been traditionally skewed downwards in the standards. However, the weight of research evidence from field studies suggests that neither the 'risk' of draft nor the possibility of negative indoor air quality posed by elevated enthalpy in buildings with natural or hybrid ventilation systems, are real enough to sacrifice the environmentally sustainable goals of bioclimatic design strategies (TANABE, 1988; FOUNTAIN et al., 1994, TOFTUM, 2004; HUIZENGA et al., 2004; ZHANG et al., 2007b; ARENS et al., 2009; CÂNDIDO et al., 2011).
The second shift is related to the understanding that occupants are perceived as active agents within the indoor environment and not only passive recipients on predetermined thermal conditions as one would expect in air-conditioning buildings. It is becoming clear that providing control availability, especially when designing naturally ventilated indoor environments is paramount for occupants' comfort, well-being and productivity (BOERSTRA, 2010; KIM; DE DEAR, 2012). This also reinforces the conclusion that designing buildings totally disconnected from the outdoor climate and environment in which they are found is becoming completely out of date. With this in mind, designers are beginning (rather slowly) to shift their attention to widening the range of opportunities available in a building to provide comfort for occupants.

The third and most recent shift proposes a new approach to indoor environmental quality, going beyond thermal comfort and reaching for thermal pleasure. Thermal comfort is defined as the state of mind that expresses satisfaction with the surrounding environment' (STANDARD 55 (AMERICAN..., 2010)). The emergent application of thermal alliesthesia to the thermal comfort explored by de Dear (2010) investigates situations in which a peripheral thermal sensation can assume either positive or negative hedonic tone, depending on the state of core temperature in relation to its thermo-neutral set-point. The concept of alliesthesia coined by Cabanac (1971) implies the presence of internal signals modifying the conscious sensations aroused from peripheral receptors. For instance accelerations in air speed on skin surface trigger dynamic discharges from the skin's cold thermoreceptors. So, in the warm adaptive comfort zone these turbulence-induced dynamic discharges from exposed skin's cold thermoreceptors elicit small bursts of positive alliesthesia (DE DEAR, 2011). This approach aligns with the adaptive model and it advocates that naturally ventilated buildings will provide indoor environments far more stimulating and pleasurable compared to the static indoor climate achieved by centralized air-conditioning (TOFTUM, 2004; HUIZENGA et al., 2004).

When combined, these three shifts reinforce the conclusion behavioural change in buildings can undoubtedly deliver fast and zero-cost improvements in energy efficiency and greenhouse gas emission reductions. In order to provide such behavioural opportunities, or adaptive opportunities, buildings must be designed to actively re-engage occupants in the achievement of 
thermal satisfaction. This paper will focus on the rationale behind these three shifts and it will discuss their positive influence when moving from thermal comfort towards thermal pleasure.

\section{Static versus adaptive approaches to thermal comfort}

The landmark research of Fanger (1970) provided the framework necessary to determine a set of design temperatures for engineering mechanically controlled indoor environments. The Predicted Mean Vote - PMV can also be used to assess given room's climate, in terms of deviations from an optimal thermal comfort situation and it has been globally applied for almost 40 years across all building types, climates and cultures all over the world even though it was originally intended for application by the heating, ventilation and airconditioning (HVAC) industry in the creation of artificial climates in controlled spaces (VAN HOOF; HENSEN, 2007). In association with the Predicted Percentage of Dissatisfied - PPD, the PMV model encouraged not only the tight setpoints necessary in order to keep people feeling 'neutral' but also, indirectly, “[...] the wholesale commoditization of the building design process, taking power from architects to service engineers [...]" (TUOHY et al., 2010). Both the PMV and PPD were and still are broadly used in standards such as ASHRAE Standard 55 (AMERICAN..., 2010), CEN CR 1752 (EUROPEAN..., 2009) and ISO 7730 (2006), and its influence in thermal comfort field is widely recognized.

As with any theory, model or index, Fanger's legacy has been both widely supported and widely criticized. In his dissertation, Fanger explained that the PMV model was derived from laboratory experiments and it should therefore be used with care for values below -2 and above +2 . Especially on the hot side, he foresaw significant errors (VAN HOOF; HENSEN, 2007). But probably the most important criticism is the concept of a universal, 'neutral' temperature. Regarding the inadequacies of PMV applications in naturally ventilated buildings de Dear and Brager (1998, p. 3) commented that,

"[...] the cool, still air philosophy of thermal comfort, which requires significant energy consumption for mechanical cooling, appears to be over-restrictive and, as such, may not be appropriate criterion when decisions are being made whether or not to install HVAC systems [...]".

The widely accepted 'adaptive comfort model' shifted this paradigm.
The dialectic between conventional, or 'static', and the adaptive comfort theories can be seen in innumerable papers and goes back few decades (AULICIENS, 1981; NICOL, 2004; HUMPHREYS, 1978; BRAGER; DE DEAR, 2001). This discussion became more prominent, however, by the end of the 20th century with the realization of the (unsustainable) energy and carbon required to air condition indoor environments. Based on an analysis of over twenty thousand row set of indoor microclimatic and simultaneous occupant comfort data from buildings around the world, the ASHRAE RP-884 database found that indoor temperatures eliciting a minimum number of requests for warmer or cooler conditions were linked to the outdoor temperature at the time of the survey. Thermal acceptability was found for 80 and $90 \%$ by applying the 10 and $20 \%$ PPD criteria to the thermal sensation scale recorded in the building. Buildings were separated into those that had centrally-controlled heating, ventilating, and air-conditioning systems (HVAC), and naturally ventilated buildings (NV). Since the ASHRAE RP-884 database comprised existing field studies, the HVAC versus NV classification came largely from the original field researchers' descriptions of their buildings and their environmental control systems. The primary distinction between the building types was that NV buildings had no mechanical air-conditioning, and that natural ventilation occurred through operable windows that were directly controlled by the occupants. In contrast, occupants of the HVAC buildings had little or no control over their immediate thermal environment.

The major conceptual departure of the adaptive model is its reference to thermal history, expectations and attitudes, perceived control and availability of behavioral thermoregulatory options. While the heat balance model is able to account for some degree of behavioral adaptation, such as changing one's clothing or adjusting local air velocity, it ignores the psychological dimension of adaptation, which may be particularly important in contexts where people's interactions with the environment (i.e. personal thermal control), or diverse thermal experiences, may alter their expectations, and thus, their thermal sensation and satisfaction. One context where these factors play a particularly important role is naturally ventilated buildings (DE DEAR; BRAGER, 2001). The model was derived largely from naturally ventilated office building in various climatic zones of the world and the general principle of weather sensitivity should be equally relevant to other contexts, including residential settings, if not more so. Adaptive comfort theory predicts that the limit 
of acceptable residential temperatures will drift up from the conventional wisdom of 23 24oC during warm weather. It also suggests that the cognitive and behavioral factors impinging on comfort in a residential setting will qualitatively differ from those in the commercial office building sector, where conventional (PMV) thermal comfort theory was originally developed.

The model was derived largely from naturally ventilated office building in various climatic zones of the world with the general principle of weather sensitivity being regarded as paramount. The adaptive model's outdoor weather-responsive comfort zone is presented as a permissible alternative to PMV within the most recent revision to ASHRAE's Standard 55 (AMERICAN..., 2010) and the European Community's counterpart document, EN15251 has since followed suit (VAN DER LINDEN et al., 2006) and it such implementation was, undoubtedly, a step forward towards mainstreaming naturally ventilated buildings (VAN DER LINDEN et al., 2006; SHASE-G, 1994). China, Brazil and India are discussing standards for naturally ventilated buildings (ZHANG, 2010; WANG; CHANG; DAUBER, 2010; THOMAS et al., 2010; CANDIDO et al., 2011). This concept has now been revisited, and the new addenda include a weighted mean daily temperature (and not monthly). This modification is yet to be discussed by the thermal comfort research community but it does show the research driven nature of this standard and that there are important questions to be answered, especially in relation to the coefficients adopted. These questions are now open for discussion and there is considerable ground to be covered on this matter.

\section{From draft to breeze}

The adaptive model of thermal comfort offered a new approach towards naturally ventilated buildings when establishing that fluctuations in temperature can still be perceived as acceptable to the occupants and this in turn has been widening the possibilities of using natural ventilation as energy conservation design strategy. Many of the justifications for the shift from naturally ventilated indoor climates to HVAC during the late 20th century emphasized the risk of local discomfort, or draft, in situations where indoor air movement relies on natural processes instead of controllable mechanical ones (MCINTYRE, 1978, FANGER et al., 1988). As a concept, draft means any unpleasant air movement and is related to air temperature and air speed but also other factors such as area and variability and which part of the body is exposed (MCINTYRE, 1978). Based on laboratory studies, an effect of turbulence intensity on draught discomfort was identified (FANGER et al., 1988) and incorporated into a model that predicts the percentage of dissatisfied due to draught as a function of mean air velocity, air temperature and turbulence intensity.

Data from laboratory experiments in cold climates has been used to justify that $0.2 \mathrm{~m} / \mathrm{s}$ as the maximum allowable air speed and it has been deemed to be the threshold of draft perception inside air-conditioned buildings. In moderate climates, draft is one of the main sources of complaint in regards to the workplace environment, concerning up to one third of office workers and at least two thirds of workers in moderately cold environments (GRIEFAHN; KUNEMUND; GEHRING, 2001). One reason for the large number of draft complaints among people working in cool or cold environments is simply because they are more sensitive to draft than people who feel thermally neutral (TOFTUM, 2004). However in warm to hot climates, draft should not be the main concern, and natural ventilation plays an important role in controlling indoor air quality, indoor temperature, and also prevents the risk of occupants overheating.

Extensive laboratory experiments have been carried out in order to understand the limits for air speed in which people would still consider as acceptable. The pioneer study by Rohles, Woods and Nevins (1974), examining the effects of air flow provided by fans, indicates that for an air speed of $1 \mathrm{~m} / \mathrm{s}$, the effective temperature can be extended to $29^{\circ} \mathrm{C}$. In a similar investigation it was found that at least $80 \%$ of the occupants can be comfortable for a temperature limit of $28^{\circ} \mathrm{C}$ and air speed of 1,02m/s (SCHEATZLE; WU; YELLOT, 1989). Other studies found that, for the same temperature and thermal acceptability, the air speed values should be from 1.0 to $1,5 \mathrm{~m} / \mathrm{s}$ (KHEDARI et al., 2000) and from 0.2 to $1.5 \mathrm{~m} / \mathrm{s}$ (FOUNTAIN, 1991). Higher values, up to $1.6 \mathrm{~m} / \mathrm{s}$, were suggested to maintain the occupants' thermal comfort for a temperature of $31^{\circ} \mathrm{C}$ (Tanabe, 1988; TABANE; KIMURA, 1994). Melikov, Arakelian and Halkjaer (1994) and Olesen and Nielsen (1983) investigated human responses to local cooling with air jets in warm conditions and found that the air jet speed preferred by the subjects was not the same as that corresponding to thermal neutrality, but the one decreasing the sensation of warmth without causing too much discomfort due to draft. These studies clearly indicate how air motion increment can influence on human thermal acceptability and comfort in warmer indoor environments. 
Field studies have also been carried out in order to understand air speed limits in warm and hot climates. The overwhelming weight of evidence from such studies indicates that increased air movement in warm and hot environments is essential in improving occupants' thermal comfort, and therefore higher air speed values are suggested for these contexts (TANABE, 1988; TOFTUM, 2004; ZHANG et al., 2007a; ARENS et al., 2009; CÂNDIDO et al., 2011). One of the most extensive and detailed study is based on the ASHRAE RP-884 database Toftum (2004), Zhang et al. (2007b) and Arens et al. (2009) found that people who feel cold prefer 'less air movement', and those who feel hot prefer 'more air movement'. Nevertheless, the distribution of air velocities measured during field studies was skewed towards rather low values. This is true even though occupants in the database buildings rarely had individual control over air movement.

A recent review of the same database carried out by Arens et al. (2009) focusing on air movement preferences concluded that for sensations from 0.7 to 1.5, air movement should be encouraged and for occupants possessing air velocity control, this limit can be extended to $0.8 \mathrm{~m} / \mathrm{s}$. One of the main conclusions is that air movement should not be made so great that it leaves people feeling cold, but a certain amount of it does answer a basic need found in the surveys, and can offset an increase in temperature in the space. Similar results have been found for a building in which occupants have personal or group control over window ventilation. Based on these findings, the authors proposed a two-step process in order to define comfort zones, considering temperature, radiant heat, humidity and air movement. This new procedure encourages elevated air speeds in combination with the standard effective temperature and occupant's control requirements. The authors pointed out the benefits of these new provisions that "allow designers to use fans, stack effects, or window ventilation to offset mechanical cooling, or in some climates, supplement it entirely" (ARENS et al., 2009).

This recent review released in 2010 represents an important step forward in providing higher air speed values. More details about what is new on ASHRAE 2010 can be found on Turner (2011). The increase in air speed values are in tune with research findings focusing on occupants' satisfaction in which experiments indicate that the draft limit should not be applied when people feel neutral or warmer. The prediction of draft discomfort overestimates the dissatisfaction percentage actually observed in naturally ventilated buildings. Field studies suggest that there may be a zone of temperatures and air velocities in which devices and designs that move air across large areas can do so without creating an 'appreciable' draft risk for the occupants. Many previous studies focused on air movement in field studies, including the maximum air velocity range that could be regarded as 'acceptable' for occupants during their activities. In this case, the considerations were constantly related to the concept of avoiding any disturbing or undesirable air movement (draft).

\section{From passive to active occupants}

The adaptive model has long insisted occupants are ultimately perceived as active agents within the indoor environment and not only passive recipients on predetermined thermal conditions as one would expect in air-conditioning buildings. It has been noted that thermal environmental conditions perceived as unacceptable by the occupants of centrally air-conditioned buildings can be regarded as perfectly acceptable, if not preferable, in a naturally ventilated buildings (FOUNTAIN et al., 1994). Given thermal environmental stimulus can elicit disparate thermal comfort responses, depending on the architectural context in which it is experienced (RAJA et al., 2001) and one of the key ingredients is control availability. Widening the adaptive opportunities i.e. allowing people to make the environmental adjustments themselves such as opening or closing a window, turning on a local fan, or adjusting an air diffuser as part of their adaptive opportunities, can be perceived as a 'bonus' for occupants (KIM; DE DEAR, 2012).

From a psychological perspective, studies reveal that offering personal control over the indoor environment seems to be very effective in minimizing negative effects, such as stress. (VROON, 1990). Other studies demonstrated that control has a direct effect in the occupants and their satisfaction with their work environment in general, acting as "compensation" (LEYTEN; KURVERS; VAN DEN EIJNDE, 2009). Data from the same authors showed that occupants tend to be more forgiving of daily malfunctions in their work environments, such as problems with equipments and systems, when they had greater degrees of freedom in adapting their immediate indoor conditions.

Relationships between occupants' control and sick building syndrome have also been found. A large field study conducted in 47 English office buildings revealed that occupants with limited control over their indoor environment were most likely to show symptoms such as dry eyes, dry throat, stuffy nose, itchy eyes and lethargy 
(HEDGE et al., 1989). Results from similar field experiments in Germany corroborate these results. Indeed occupants with limited control generally showed more signs of sick building symptoms (ZWEERS et al., 1992).

Focusing on thermal comfort, other researchers found that occupants with access to desk lighting, windows and adjustable HVAC set points are by far more satisfied with their work environments than those occupants without these opportunities Boerstra (2010). Results from a large survey in the US provide further indications of the control satisfaction relationship (HUIZENGA et al., 2004). An extensive study carried-out in mixedmode buildings in the US clearly show that the main reasons for dissatisfaction with the indoor environment were related to lack of control (BRAGER; BAKER, 2009). Occupants reported complaints such as temperature ('my area is hotter/colder than other areas'), control ('thermostat is inaccessible' or 'adjusted by other people'), lack of air movement ('air movement too low'), and speed of response ('heating/cooling system does not respond'. People value operable windows for a wide variety of reasons - personal control of their thermal environment, increased air movement, perceived fresh air, and connection to the outdoors (BRAGER; BAKER, 2009). Findings also show that occupants overall satisfaction will be influenced by indoor environment factors on linear fashion and as such any increment or decrement of equal magnitude in the indoor environment will indeed result in change on 'occupant's satisfaction ratio' (KIM; DE DEAR, 2012).

Offering occupants control over their indoor climate results in fewer health symptoms, higher comfort satisfaction rates and improved performance of building occupants (BRAGER; BAKER, 2009; LEYTEN; KURVERS; VAN DEN EIJNDE, 2009; BOERSTRA, 2010). Based on this evidence, it seems very logical to include the aspect of personal control over indoor climate in future thermal comfort standards. The recent review for ASHRAE (AMERICAN..., 2010) attempts to include such requirements. This rationale is intrinsically linked with the new air movement requirements and it is requested for air speeds higher than $0.8 \mathrm{~m} / \mathrm{s}$. Hopefully this new provision will encourage more control availability and greater degrees of freedom for occupants when adapting their immediate indoor conditions.

\section{From thermal boredom to thermal delight}

In a classic paper entitled "The physiological role of pleasure” Cabanac (1971) explained that in light of this theory, it is possible to reconsider the nature of the whole conscious experience. The existence of alliesthesia implies the presence of internal signals modifying the conscious sensations aroused from peripheral receptors. This conscious experience, as a result of a stimulus, can be pleasant or unpleasant, and it will be related to the subject's internal state (DE DEAR, 2010). Cabanac coins the word 'alliesthesia' to describe this occurrence perceived by human senses. Alliesthesia is essential to regulatory negative feedback systems relying on behavioural interventions, such as: hunger, thirst and thermoregulation (CABANAC; MASSONET; BELAICHE, 1972).

The emergent application of thermal alliesthesia to the thermal comfort investigates situations in which a peripheral thermal sensation can assume either positive or negative hedonic tone, depending on the state of core temperature in relation to its thermo-neutral set-point. A slight breeze on the skin brings thermal pleasure ('breeze') when the core temperature is displaced slightly above neutral. Yet the same peripheral air movement is perceived as an unwanted 'draught' if the core temperature is below its set-point”. The schematic Figure 1 shows these interrelations between the negative alliesthesia as result of antagonism between core and periphery and the positive alliesthesia as a result of the complementary relationship between core and periphery.

When we perceive warmth or coolth, we do not actually sense the temperature of the room's air or surfaces directly, but rather our nerve endings, the thermoreceptors, which send signals to the hypothalamus at the base of the brain when stimulated (ZHANG, 2003). Although it is difficult to quantitatively evaluate differences in the density of skin thermoreceptors in humans, the density of hot and cold spots would be expected to correlate positively with the density of warm and cold receptors (NAKAMURA; YODA; CRAWSHAW, 2008). Skin thermoreceptors provide the data from the environment to compare against deep body temperature (the controlled variable). The rate of firing (i.e. frequency of neural output) of skin thermoreceptors has a steady-state component, and a transient component (i.e. firing frequency). Accelerations in air velocity on skin surface trigger dynamic discharges from the skin's cold thermoreceptors. So, in the warm adaptive comfort zone these turbulence-induced 
dynamic discharges from exposed skin's cold thermoreceptors elicit small bursts of positive alliesthesia (DE DEAR, 2011). When the core temperature is warmer than the core set-point, any peripheral stimulation of cutaneous cold receptors will trigger positive alliesthesia. In light of this theory, the fluctuations in temperature and air movement in naturally ventilated buildings would be regarded as thermal pleasure by the occupants (DE DEAR, 2011).

The thermal pleasure or 'thermal delight' already explored by Heschong (1979) aligns with the adaptive model and it provides more evidence why naturally ventilated indoor environments would provide more satisfied occupants. Researching the interaction of peripheral and core thermal states as they relate to thermal pleasure and displeasure holds considerable promise for the design of energy-efficient indoor environments. However, such research requires control over internal and peripheral thermal states, suggesting an experimental method based on controlled climatic conditions rather than uncontrolled studies in field settings.

\section{Conclusions}

The dialectic between conventional and the adaptive comfort theories became more prominent by the end of the 20th century with the realization of the (unsustainable) energy carbon required to air conditioned indoor environments. The adaptive comfort showed that occupants play an active role in creating their own thermal preferences and satisfaction with an indoor environment occurs through appropriate adaptation. The ASHRAE adaptive model offered a new approach towards naturally ventilated buildings and it's broadly influence is recognized within the thermal comfort research field. On the most recent review, among other important modifications, three can be highlighted:

(a) implementation of higher air speeds;

(b) provision of occupants control over their indoor environment; and

(c) different methods for acquiring outdoor mean temperature, including a weighted daily mean of daily temperatures.

These modifications are strongly aligned with recent findings and it illustrates the research driven nature of this standard.

The revival of natural ventilation as a research topic corroborates the importance of this design strategy in providing stimulating indoor environments. Naturally ventilated buildings indeed provide indoor environments with higher percentages of occupants overall satisfaction and it presents enormous potential in contributing to energy conservation challenges faced by the building sector. There are important questions remaining related to allowable air velocity values (maximum) and occupants control within the occupied zone that should be investigated in more depth. Much has been done focusing when air movement is 'unwelcome' (i.e. draft) but there is an enormous potential in research considering air movement enhancement in buildings as a 'welcome breeze'. Especially in hot-humid climates, this research topic is pivotal in providing thermally acceptable indoor environments and occupants' satisfaction.

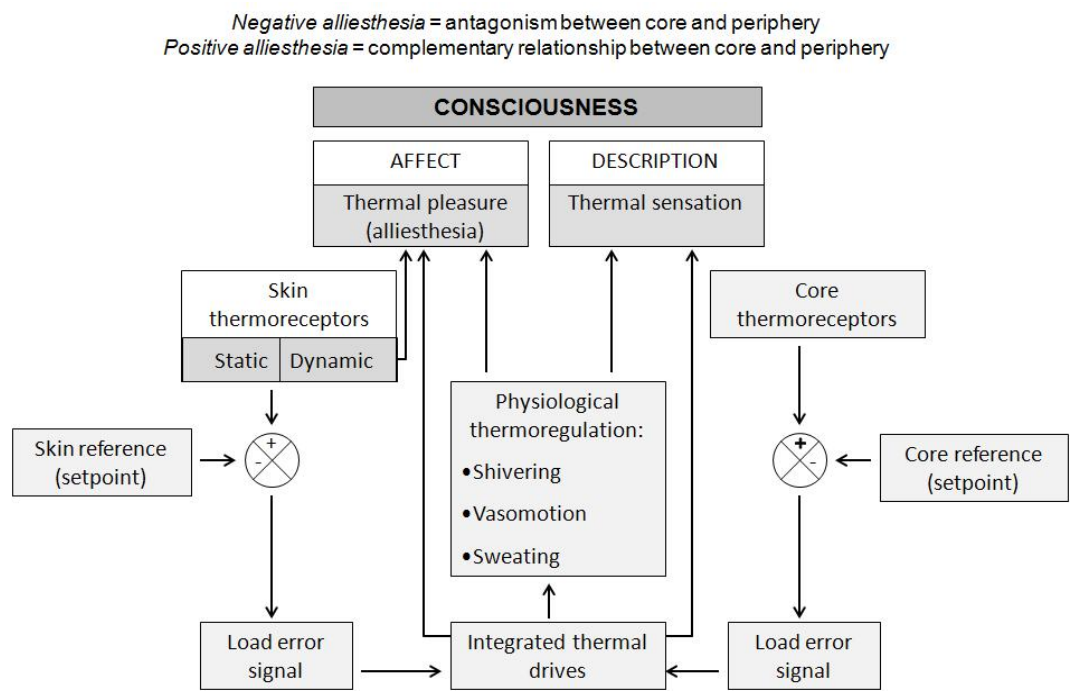

Figure 1 - Negative and positive alliesthesia

Fonte: de Dear (2010). 
The emergent topic of alliesthesia can provide more insightful information about this complex and fascinating interaction between physiology and pleasure. Clearly, a specific air speed has many possible physiological and subjective effects ranging from a pleasant sense of coolness to an unpleasant sense of draft, depending on the status of the indoor climate variables and the occupants' individual factors. Designers should therefore explore it more fully on their design, focusing on more sustainable, energy efficient and, why not, pleasurable built environmental designs.

\section{References}

ARENS, E. et al. Moving Air For Comfort.

ASHRAE Journal, p. 18-29, 2009.

AMERICAN SOCIETY OF HEATING, REFRIGERATING \& AIR-CONDITIONING ENGINEERS. Standard 55: thermal environmental conditions for human occupancy. Atlanta: ASHRAE, 2010.

AULICIEMS, A. Towards a Psycho-Physiological Model of Thermal Perception. International Journal of Biometeorology, v. 25, n. 2, p. 109122, 1981.

BOERSTRA, A. Personal Control in Future Thermal Comfort Standards? In: ADAPTING TO CHANGE: NEW THINKING ON COMFORT, Windsor, UK, 2010. Proceedings... London: Network for Comfort and Energy Use in Buildings, 2010.

BRAGER, G.; BAKER, L. Occupant Satisfaction in Mixed-Mode Buildings. Building Research \& Information, v. 37, n. 4, p. 369-380, 2009.

BRAGER, G.; DE DEAR, R. Climate, Comfort and Natural Ventilation: a new adaptive comfort standard for ASHRAE Standard 55. In: WINDSOR CONFERENCE 2001: MOVING THERMAL COMFORT STANDARDS INTO THE $21^{\text {ST }}$ CENTURY, Windsor, UK. 2001. Proceedings... Windsor, UK, 2001.

CABANAC, M. Physiological Role of Pleasure. Science, v.17, p. 1103-1007, 1971.

CABANAC, M.; MASSONNET, B.; BELAICHE, R. Preferred Skin Temperature as a Function of Internal and Mean Skin Temperature. Journal of Applied Physiology, v. 33, n. 6, 699-703, dez. 1972.

CÂNDIDO, C. et al. Air Movement Acceptability Limits and Thermal Comfort in Brazil's Hot Humid Climate Zone. Building and

Environment, v. 45, n. 1, p. 222-229, jan. 2010.
CÂNDIDO, C. et al. Towards a Brazilian Standard For Naturally Ventilated Buildings: guidelines for thermal and air movement acceptability. Building Research and Information, v. 39, n. 2, p. 145153, 2011.

DE DEAR, R. Thermal Comfort in Natural Ventilation: a neurophysiological hypothesis. In: 2010 WINDSOR CONFERENCE: ADAPTING TO CHANGE: NEW THINKING ON COMFORT, 6., Windsor, UK, 2010. Proceedings... Windsor, UK, 2010.

DE DEAR, R. Revisiting an Old Hypothesis of Human Thermal Perception: Alliesthesia. Building Research and Information, v. 39, n. 2, p. 108117, 2011.

DE DEAR, R.; BRAGER, G. S. Developing an Adaptive Model of Thermal Comfort and Preference. ASHRAE Trans, v. 104, part 1A, p. 145-167, 1998.

\section{EUROPEAN COMMITTEE FOR}

STANDARDIZATION. CR 1752: ventilation for buildings: design criteria for the indoor environment. Brussels, 2005.

FANGER, P. O. Thermal Comfort: analysis and applications in Environmental Engineering. Copenhagen: Danish Technical Press, 1970.

FANGER, P. O. et al. Air Turbulence and Sensation of Draught. Energy Build, v. 12, p. 2129, 1988.

FOUNTAIN, M. E. Laboratory Studies of the Effect of Air Movement on Thermal Comfort: a comparison and discussion of methods. ASHRAE Trans, v. 97, n. 1, p. 863-873, 1991.

FOUNTAIN, M. E. et al. Locally Controlled Air Movement Preferred in Hot Isothermal Environments. ASHRAE Trans, v. 100, n. 2, p. 937-952, 1994.

GRIEFAHN, B.; KUNEMUND, C.; GEHRING, U. The Impact of Draught Related Air Velocity, Air Temperature and Workload. Applied Ergonomics, v. 32, n. 4, p. 407-417, 2001.

HEDGE, A. et al. Work-Related Illness in Offices: a proposed model of the 'Sick Building Syndrome'. Environment International, v. 15, p. 143-158, 1989.

\section{HESCHONG, L. Thermal Delight in}

Architecture. Cambridge Mass: MIT Press, 1979.

HUIZENGA, C. et al. Listening to the Occupants: a Web-Based Indoor Environmental Quality Survey. Indoor Air, v. 14, suppl. 8, p. 65-74, dez. 2004. 
HUMPHREYS, M. A. Outdoor Temperatures and Comfort Indoors. Building Research and Practice, v. 6, n. 2, p. 92-105, 1978.

INTERNATIONAL ORGANISATION FOR STANDARDISATION. ISO 7730: moderate thermal environments, determination of the PMV and PPD indices and specification of the conditions for thermal comfort ISO. Geneva, Switzerland, 2006.

KIM, J.; DE DEAR, R. Nonlinear Relationships Between Individual IEQ Factors and Overall Workspace Satisfaction. Building and Environment, v. 49, p. 33-40, mar. 2012.

KHEDARI, J. et al. Thailand Ventilation Comfort Chart. Energy and Buildings, v. 32, p. 245-249, 2000.

LEYTEN J. L.; KURVERS, S. R.; VAN DEN EIJNDE, J. Robustness of Office Buildings and the Environmental Gestalt. In: PROCEEDINGS OF HEALTHY BUILDINGS. 2009. v. 2, p. 130-133.

MCINTYRE, D. A. Preferred Air Speed for Comfort in Warm Conditions. ASHRAE Trans, v. 84, n. 2, p. 263-277, 1978.

MELIKOV, A. K.; ARAKELIAN, R. S.; HALKJAER, L. Spot Cooling, Part 1: human responses to cooling with air jets. ASHRAE Transactions, v. 100, n. 2, p. 476-99, 1994.

NAKAMURA, M.; YODA, T.; CRAWSHAW, L. I. Regional Differences in Temperature Sensation and Thermal Comfort in Humans. Appl Physiol, v. 105, n. 6, p. 1897-1906, dez. 2008.

NICOL, F. Adaptive Thermal Comfort Standards in the Hot-Humid Tropics. Energy and Buildings, v. 36, n. 7, p. 628-637, jul. 2004.

OLESEN, B. W.; NIELSEN, R. Convective Spot Cooling of Hot Working Environment. In: INTERNATIONAL CONFERENCE OF REFRIGERATION, 16 ${ }^{\mathrm{TH}}$., Paris, 1983. Proceedings... Paris, 1983. p. 201-207.

RAJA, L. A. et al. Thermal Comfort: use of controls in naturally ventilated buildings. Energy and Buildings, v. 33, n. 3, p. 235-244, 2001.

ROAF, S.; CRICHTON, D.; NICOL, F. Adapting Buildings and Cities for Climate Change. $2^{\text {nd }}$ ed. Oxford: Architectural Press, 2009.

ROHLES, F. H.; WOODS, J. E.; NEVINS, R. G. The Effect of Air Movement and Temperature on the Thermal Sensations of Sedentary Man.

ASHRAE Trans, v. 80, p. 101-119, 1974.

SHASE-G 0001-1994. Technical Guideline for Energy Conservation in Architecture and Building Services, Japan. 1994.
SCHEATZLE, D.; WU, H.; YELLOT, J. Extending the Summer Comfort Envelope With Ceiling Fans in Hot, Arid Climates. ASHRAE Trans, v. 95, n. 1, p. 269-280, 1989.

TANABE, S. Thermal Comfort Requirements in Japan. Tokyo, 1988. PhD Thesis. Waseda University, Tokyo, 1988.

TANABE, S.; KIMURA, K. Effects of Air Temperature, Humidity and Air Movement on Thermal Comfort Under Hot and Humid Conditions. ASHRAE Trans, v. 100, n. 2, 1994.

THOMAS, L. et al. Air Conditioning, Comfort and Energy in India's Commertial Building Sector. In: ADAPTING TO CHANGE: NEW THINKING ON COMFORT, Windsor, UK, 2010.

Proceedings... London: Network for Comfort and Energy Use in Buildings, 2010.

TOFTUM, J. Air Movement-Good or Bad? Indoor Air, v. 14, suppl. 7, p. 40-45, 2004.

TUOHY, P. et al. Twenty Century Standards for Thermal Comfort: fostering low carbon building design and operation. Architectural Science Review, v. 53, n. 1, p. 78-86, 2010.

TURNER, S. What's New in ASHRAE's Standard on Comfort. ASHRAE Journal, n. 53, n. 6, p. 4248, jun. 2011.

VAN DER LINDEN, A. C. et al. Adaptive Temperature Limits: a new guideline in The Netherlands, a new approach for the assessment of building performance with respect to thermal indoor climate. Energy and Building, v. 38, n. 1, p. 8-17, 2006.

VAN HOOF, J.; HENSEN, J. L. Quantifying the Relevance of Adaptive Thermal Comfort Models in Moderate Thermal Climate Zones. Building and Environment, v. 42, n. 1, p. 156-170, 2007.

VROON, P. A. Psychological Aspects of IllnessCausing Buildings. Utrecht, 1990. PhD Thesis,University of Utrecht, Utrecht, 1990.

WANG, N.; CHANG, Y. C.; DAUBER, V. Carbon Print Studies for the Energy Conservation Regulations of the UK and China. Energy and Buildings, v. 42, n. 5, p. 695-698, 2010.

ZHANG, H. Human Thermal Sensation and Comfort in Transient and Non-Uniform Thermal Environments. Berkeley, 2003. PhD thesis, University of California, Berkeley, 2003.

ZHANG, H. et al. Air Movement Preferences Observed in Office Buildings. International Journal Biometeorology, v. 51, n. 5, p. 349-360, 2007a. 
ZHANG, G. et al. Thermal Comfort Investigation of Naturally Ventilated Classrooms in a Subtropical Region. Indoor and Built

Environment, v. 16, n. 2, p. 148-158, 2007b.

ZHANG, Z. X. Is It Fair to Treat China as a Christmas Tree to Hang Everybody's Complaints? Putting its own energy saving in perspective.

Energy Economics, v. 32, suppl. 1, S47-S56, set. 2010.
ZWEERS, T. et al. Health and Indoor Climate Complaints of 7043 Office Workers in 61

Buildings in the Netherlands. Indoor Air, v. 2, n. 3, p. 127-136, 1992.

Revista Ambiente Construído

Associação Nacional de Tecnologia do Ambiente Construído

Av. Osvaldo Aranha, 99 - 3o andar, Centro

Porto Alegre - RS - Brasil

CEP $90035-190$

Telefone: +55 (51) 3308-4084

Fax: +55 (51) 3308-4054

www. seer. ufrgs. br/ ambienteconstruido

E-mail: ambienteconstruido@ufrgs.br

90 Candido, C.; de Dear, R. 